\title{
Crossing borders as 'new' academics in contested times: Reflexive narratives of curriculum change and transformation
}

\author{
Bradley Rink ${ }^{1}$, Kharnita Mohamed ${ }^{2}$, Asanda Ngoasheng ${ }^{3}$ and Kasturi Behari-Leak ${ }^{2}$ \\ ${ }^{1}$ University of the Western Cape \\ ${ }^{2}$ University of Cape Town \\ ${ }^{3}$ University of Sussex \\ Corresponding Author: brink@uwc.ac.za
}

(Submitted: 7 November 2019; Accepted: 8 April 2020)

\begin{abstract}
This paper takes a reflexive and narrative approach to exploring three academics' journeys of curriculum transformation at the height of the \#Rhodesmustfall and \#Feesmustfall movement in South Africa. Their narratives tell the story of individual and shared border crossings which illustrate how 'new' academics transcend limitations and separations between people, knowledge and curricula. Decoloniality in curricular and pedagogical change are explored through the lenses of the three academics and an academic developer supporting their journey. The narratives show that decolonial curricular and pedagogies are about good teaching and a greater understanding of students and their needs. Authors' reflexive narratives are deeply informed by the contexts in which they are implementing curriculum transformation. This paper is underpinned by the theoretical framework of Archer's social realism, reflexive curricula, and border crossing. Reflecting on their curriculum transformation journeys, the authors come to realise that openness to learning is the key ingredient required for curriculum change to take place so that higher education can be accessible and relevant to the majority of students.
\end{abstract}

Keywords: curriculum change, intradisciplinarity, new academics, positionality, social realist theory, reflexive pedagogies,

\section{Introduction}

I am not impartial or objective; not a fixed observer of facts and happenings

- Paulo Freire, Pedagogy of Freedom 
This paper is about three new ${ }^{1}$ academics and an academic developer's journey through different but intersecting border crossings in South African higher education. Using a reflexive methodology, we provide narratives to re-imagine curriculum change and transformation in three different academic and disciplinary contexts. This paper will use narratives to reflect on how we are all border crossers in our academic and personal journeys (Freire, 2000). Border crossings are important to transcend limitations and separations between people, knowledge, disciplines and curricula. We chose to transcend borders towards liberatory ends because of our consideration of our positionality and a commitment to creating socially just futures. This paper sketches the connections between our work as border crossers and how this shaped our pedagogies and contributed to transformation curriculum in our respective disciplines, sometimes at great cost to self.

As academics, our positionalities influence the curricular borders we choose to dismantle and those we leave intact. Our constitution as a group reflects four individual positionalities that intersect on the historical gridlines of race, gender, age, and ethnicity. We are three black female and one white academic of varying ages teaching at different institutions, targeted at middleand working-class students in Cape Town, South Africa. While our identities, institutional settings, and disciplines differ, we share the goal of curriculum change and transformation. We seek to re-imagine a socially just future direction of/in higher education curricula development.

Our paths first intersected at the New Academics' Transitions Regional Colloquium (NATRC) in 2017, an event initiated by the University of Cape Town (UCT) and convened by Kasturi. NATRC was a collaboration between staff development units at the University of the Western Cape (UWC), the Cape Peninsula University of Technology (CPUT), and Stellenbosch University. NATRC sought to bring together new academic practitioners from the Western Cape to discuss, share, develop, and engage with what it means to be a new academic. This type of supportive space is critical for teaching and learning success in the post-colonial classroom (Behari-Leak, 2017). The NATRC project took place at the height of the \#RhodesMustFall and \#FeesMustFall movement protests and institution shutdowns which took place in 2015, 2016, and 2017.

At the colloquium, the 'new' academics at each institution shared the pedagogical interventions they had implemented in their classrooms and the challenges they experienced in the process of curriculum transformation. Our coming together as authors happened over a series of project meetings where three clusters emerged. Our cluster focused on curriculum change as we had all challenged the disciplinary and pedagogical borders we had inherited from previous subject lecturers. We also were all experienced practitioners and lecturers but were officially considered new academics at our institutions and in our subjects. In this paper, we

\footnotetext{
${ }^{1}$ We were brought together through the New Academics' Transitions Regional Colloquium (NATRC) in 2017. While none of us would consider ourselves new to the higher education sector, we are all new either to our institutions, our positions, or our stance on the leading edge of curricular change. We all understand that being considered 'new' and the 'next generation' of academics is in tension with the precarious nature of labour in the sector.
} 
demonstrate the value of reflexive pedagogies which allowed us to claim ownership of our subjects and our curricula. At a moment when identity, positionality and politics matter more than ever in the spaces of teaching and learning, we assert that challenges and opportunities can be mediated by bringing ourselves fully into classrooms.

\section{Background and institutional contexts}

The NATRC colloquium took place in May 2017, after the 2015 protests when students at UCT started the \#RhodesMustFall ${ }^{2}$ movement (\#RMF), which later became the \#FeesMustFall ${ }^{3}$ movement (\#FMF) that spread across all campuses in South Africa and beyond. Students protested and at times shutdown different campuses at different times from 2016 to 2017 . This was a difficult time in South African higher education. Our academic institutions were all affected by student protests but the impact on campuses, the teaching and learning project, studentlecturer relationships, academic and student morale were experienced in different ways. Experiences $^{4}$ depended on how the different entities saw themselves and Others: as victims, perpetrators or both and reactions varied across different campuses. Physical and epistemic violence were prevalent across all campuses with students burning buildings, increased militarisation of campus by management and characterisation of students as hooligans and 'uncivilised savages' in the media. However, urgent introspection about the curriculum and the need for curriculum transformation took place at this time, amidst grave tensions between management, academics and students.

At UCT, students challenged the university to look at how it perpetuated exclusion through epistemic obedience to the global North. Student protests disrupted colonial sensibilities around art and building names and challenged hierarchies of traditional power that had been reproduced uninterrupted before (Farber, 2015). Three key sites emerged as the centre of contestation, Health Sciences, Fine Arts, and the College of Music. Fallist student activists interrogated teaching, learning, assessment, administration, and management practices which led black students in particular, to feel isolated, marginalised, voiceless, and excluded. One of the institutional responses to protest at UCT was a Curriculum Change Working Group (CCWG) established in 2016 to facilitate discussions, out of which a Framework for Curriculum Change emerged (CCWG, 2018).

\footnotetext{
${ }^{2}$ \#RhodesMustFall was a protest movement that began on 9 March 2015, originally coalesced against the now removed, Cecil Rhodes statue at UCT and then led to a wider movement to 'decolonise' education across South Africa (Chikane, 2018).

${ }^{3}$ \#FeesMustFall was a student-led protest movement that began in mid-October 2015 in South Africa, to stop increases in student fees as well as to increase government funding of universities (Chikane, 2018).

${ }^{4}$ Indeed, for all of us, the source of this knowledge comes from a multitude of channels including official university communications, media reports, social media, personal communications between us, our students and fellow academics, and especially personal observations. In many cases, the sources cannot be documented in traditional academic ways, as the state of affairs at the start of \#FMF was characterised by exceptional fluidity, obfuscation of events on-the-ground, and multiple (and competing) narratives. We have attempted to remain faithful to the experiences that each of us had, firmly in-line with our stance on the importance of positionality and context.
} 
Cape Peninsula University of Technology (CPUT) was established through a merger of various racially segregated institutions and trade schools including Cape Technikon and Peninsula Technikon. The merger was done in order to produce a multi-racial, post-apartheid institution (Garraway and Winberg, 2019). It has a majority black working-class student body, mainly from Cape Town, with most students requiring financial aid to complete their studies (Hall, 2015). This history had implications for the university's response to the calls for decolonisation of the curriculum and the greater \#RMF and \#FMFs movements. At CPUT, student demands also went beyond calling for free education to asking for historical debt to be written off for all previous students. This demand was eventually acceded to by management; however, on race, class, gender, LGBTQIA, and transgender issues, the institution discouraged and actively shut down any spaces for students and staff to debate and discuss contestations (Ndelu, 2017). Students protested and the university brought in more militarised private security at a huge cost, at a time when the institution claimed to not have sufficient funds to meet students' infrastructure demands. The relationship between management, staff and students was fraught with mistrust, which escalated when management at some institutions, including CPUT, went as far as placing barbed wire around the now militarised campuses. In each \#FMF campus shutdown period, CPUT had the longest shutdowns, with protests continuing long after other universities had resumed classes.

University of the Western Cape is historically a coloured (black) university with a strong record of anti-apartheid struggle. The \#FMF protest period awakened many students and staff members to the need for institutional and curricular change. UWC students supported the call for more equitable access, better support for financially- and academically challenged students, and a more relevant and Africanised curriculum (Ndelu, 2017). Although UWC is often dubbed as the 'intellectual home of the Left' in South African higher education (University of the Western Cape, 2020), there were tensions between old and new activists. Protesting students burnt buildings and management responded by shutting campus down for extended periods. There were limited pockets of change in how academics conducted their lectures, related to students and interacted in departmental meetings but for many it was business-as-usual. Curriculum change happened to some extent but was not met with universal acceptance.

\section{Theoretical framing}

We take inspiration from Archer's (2003) thesis that reflexivity, agency and reflexive internal conversations are needed to negotiate our structural and cultural contexts. These conversations are influenced by the structural and cultural systems we inhabit, which trigger personal properties and powers to respond to context. In a sense, Archer's social realism offers an invitation to agents to talk back to their conditioning contexts and choose whether to be passive and reproductive or active and transformative. In this paper we articulate and enact choices linked strongly to a social justice agenda. As shown in our reflections, we each experienced the espoused and enacted curriculum as alienating, marginalising, and invisibilising, not just of ourselves as new academics, but of our students. According to Archer (2003), we all come into the world with 
'ultimate concerns' as individuals and educators. Our reflexive processes in this paper are thus framed by theories of curriculum change, the role of reflexivity, and the experience of border crossing. In the end, curriculum change has become a manifestation of our concerns and commitments and extends beyond pedagogy.

\section{Curriculum change}

Calls to decolonise South African curricula have instituted at least three debates on change, according to the Council on Higher Education (2017). First, changing curriculum content so the majority of South African students are not alienated and dispelling singular paradigms so as to engage intimately with our context. Second, is changing how content is taught to broaden access to knowledge. Third, changing the ownership of knowledge to question whose knowledge is centred and ask who teaches and produces knowledge. Thinking about curriculum change for the United Kingdom, Barnett, et al. (2001) characterise curricular shifts as moving towards a performative modality of knowing which constitutes students' identities through three fluid domains in a knowledge field: knowledge (discipline-specific competencies), action (practice of disciplinary competencies) and self (educational identities). Rewriting our curricula was intended to change all three dimensions for students and ourselves towards a decolonial praxis. Whilst some disciplines easily accommodate curriculum change and rely on epistemic diversity for disciplinary renewal (Gruba, et al., 2004; Krishnan, 2009; Shumway and Messer-Davidow, 1991), Gruba, et al. (2004) found in their study of computer science departments in Australasia that curriculum change was largely driven by politics, individuals and academic fashion. In a more recent and relevant example, Quinn (2019) demonstrates the disruptive origins and possibilities of/for curricular change.

\section{Reflexive curricula}

The curricula we developed were deeply reflexive with regard to ourselves as academics, our students, the knowledge(s) we seek to develop, and the transformations we wish to enact through our teaching. In her discussion of reflexivity in qualitative research, Pillow (2003: 181) provides four reflexive strategies: 1) reflexivity as recognition of self, 2) reflexivity as recognition of other, 3 ) reflexivity as truth, and 4) reflexivity as transcendence. Although Pillow focuses primarily on reflexivity in research, we also value the application of her strategies and approach to pedagogy. From an Archerian (2003) (social realistic) perspective, the self is strongly connected to agency, which in turn has influence on structural and cultural systems. Agency is what brings about change. Reflexivity of the self thus allows us to 'disclose' our subjectivities and 'unshackle' ourselves in our practice (Pillow, 2003: 182). Similarly, in our role as teachers, we recognise what our students bring to the classroom and use that in becoming teachers who 'focus on what the student does and how that relates to teaching' (Biggs and Tang, 2011: 20). Pillow's third reflexive strategy focuses on truth, which places the spotlight on the authenticity of our teaching. Our reflexive narratives speak to truths in our structural and cultural contexts. And finally, our 
reflexivity expresses our desire to transcend our subjectivities and contexts to create change. To push institutional and our own boundaries, required border crossings.

\section{Border crossings}

Crossing borders in higher education pedagogy entails challenging and redefining the status quo (Jackson, 1997). Inspired by Freire (1985), Giroux (1992), and hooks (1994), Jackson (1997) argues for feminist pedagogy that, as its central concern, considers difference. As she notes, ' $f$ ]eminist theories...consider not just the border crossings, but also what prevents border crossings being made' (Jackson, 1997: 462). Taking cues from both feminist and queer theory, Elder (1999) argues that queerness helps to interrogate the entanglement of multiple and intersecting identities that we perform. He understands queerness

... as a theoretical and personal insistence to study the relationships between social boundaries (like 'race', gender, sexuality and class). Queerness is not only a device for thinking through issues related to sexuality. Queer theory, like feminist theory and some might argue geography even, seeks to transcend the boundaries of academic disciplines. (Elder, 1999: 88)

Thus, queer and feminist perspectives are useful in understanding border crossings, which require reflexivity, transgression, and negotiation. Curriculum change inspired by the political shifts on our campuses, contending with our own and our students' positionalities enforced reflexive responses to our curricula which were manifested as pedagogical border crossings.

\section{Methodology}

The methodology used in our analysis of curricular change and transformation is a reflexive and narrative one, following Pillow (2003) and Archer $(2000,2003)$ who together embrace knowledge that emanates from deliberate and purposive reflection. Our method of inquiry, guided by NATRC and associated meetings, is both a process and product of reflecting deeply on how we are entangled within our worlds to show how data and researcher are mutually constituted. As a method, it is socially-just and politically engaged, and following Richardson (2000: 929), is a form of 'creative analytic practice ethnography' . We see ourselves as subjects and subjectivities; deeply reflecting on our fullness as human beings and academics, hoping to undo relational damage caused by our complex and wounded past. Through our creative analytic practices of reflection and writing, we aim to cross canonical borders which would impose limits on how we express our embodied and authentic selves.

We started this process by presenting our teaching projects at the NATRC with twenty fellow new academics from the Western Cape. Presentations of our experiences and teaching practices highlighted shared concerns that organically led us into clusters with others paying attention to similar issues. After the initial Colloquium, clusters met in various locations around the Western Cape. Through a process of further reflection, discussion, and writing, we settled 
upon a shared interest in curricular transformation. Guided by our cluster coordinator, we then refined our narratives to understand our identity intersections and divergences, academic journeys, and curricular interventions. This process was not without its complexities and tensions. The collaborative engagements among the four authors surfaced disciplinary, contextual, institutional and biographical nuances embodied in each of us. For example, we each had different orientations to research and had been 'trained' in different research traditions which had become disciplined and internalised in each of us as normative. We wrote our first narratives informed by these internalised research traditions and then conducted peer reviews of each other's narratives which surface gaps and blind spots in our thinking and processing.

Group discussions urged us to revisit our own views on 'empirical' research and challenge and disrupt our research assumptions. Through the continuous process of writing, reflecting and discussion, our rationales for curriculum change, border crossings, and reflexive pedagogies within the context of our disciplines began to coalesce. Our narratives went through various sessions of peer review with new points highlighted at each session and the various threads connecting our stories emerging more at each session. Our data set comprises four narratives generated as self-critical reflections on our teaching contexts as 'new' academics and facilitator and our experiences and rationales in developing our courses.

\section{Our individual journeys as new academics}

Our stories shed light on our unique identities, structural and cultural contexts, and professional journeys as new academics. Drawing on these reflections, we turn to analysis of salient themes that contribute to the re-imagining and future directions in higher education curricula in South Africa.

\section{Kasturi's narrative: Biographies and geographies of new positionalities in context: who's inducting whom?}

As convenor of the New Academics Practitioners' Programme (NAPP) at UCT, I had noticed that academics recruited to the university in the last few years, especially after the start of \#MustFall student movements, embodied bold expressions of Self and positionality when they took up their new appointments. As a black, heterosexual female of Indian ancestry myself, I had experienced a similar need to assert my being and Self in my work but felt that I could not do so fully because the context was not conducive to understanding intersectionality in relation to academic labour. Intersectionality, was coined by Kimberlé Crenshaw in 1989 and refers to the interplay between different markers of social difference such as race, gender, sexual orientation, class, (dis)ability, nationality, religion, etc that affect our authority and power as social beings (Carbado, et al., 2013). The Fallist student protests created the environment for a (re)newed energy and urgency among new 'recruits' to bring themselves fully to their work, without following recipe-like formulas. Where 'new' has often been conflated with 'inexperience', even 'incompetence', 'new' was now manifesting in ways not paralysed by borders of difference. Institutions were also hiring academics from industry and 
academia who had some prior experience or subject or teaching but were considered new at the institutions where they participated in the induction training.

Recognising that our institution is a microcosm of a South African society, struggling to recover from dehumanisation under apartheid and colonisation, it looked to me that these new lecturers (young and old in age), were prepared to take on the mantle of critical agents committed to new beginnings and change and were looking for a way to contribute, be seen and heard and to make a difference. Whether this was a particularity of the context, the institution, the temporal frame, the pedagogical mediations or the curriculum, what hit home was that induction cannot be done to people; it is a process with people, of moving together from unknown to known, from strange to familiar but also needs to harness fresh perspectives that new people bring to old issues. Immersion in difficult structural and contextual spaces is an induction in and of itself. Creating conditions for new academics to respond in uniquely individual yet critical and collaborative ways is what matters.

It also occurred to me that new academics arriving at UCT, had set foot in a very different social and political sensibility, which was making its voice heard in lecture rooms. It is into this context that new academics have to be inducted. The aim cannot be to assimilate newness into oldness to the point of erasure and silence; cookie-cutter approaches actually do not 'cut it'. I realised that ironically, UCT being the original site of the \#MustFall student movement, the most potent of the decade, it might be a sought-after destination now for different reasons. UCT represents the potential that a colonial bastion has to re-invent itself in the wake of students' interrogation of its traditional practices and beliefs. Of course, this romanticised perspective assumes that new foot soldiers understand that being called out by students, being challenged in class, being asked to account for one's prejudice is the new lingua franca of the new higher education classroom, especially at UCT. The regional colloquium was a temperature check to see if issues pervasive across contextual boundaries evoked responses and strategies that drew on individual or communal theories of change. I was curious to see how new academics in distinctly different contexts, yet in close proximity to each other, were going about their transitions into higher education. If context matters, and it does, I wanted to see how issues such as alienation, marginalisation, silencing and invisibility, which are ontologically, conceptually and theoretically similar across the campuses, were unfolding.

With this in mind, and being concerned about the numerous obstacles to the development of our universities as places and spaces where both students and staff feel safe and can thrive, new academics' contributions showed that they were responding by disrupting institutional disciplinary and social boundaries. What emerged was a recognition to minimise the old siloed and almost territorial ways of working. This recognition required us to refocus energy to build on the collaborative and collective agency, manifested in the new groups, task teams, public intellectual debates and discussions and social justice initiatives that emerged as a result of the disruptions. Exploring context in this way therefore became critical to understanding how people respond to spaces and places they inhabit and how they work with the opportunities and constraints thrown at them. Such is the nature of emergence. If one can 
transcend the false, imposed, colonial boundaries of geography and reason to discover new options for change, the possibilities are endless. Induction programmes can create the conditions for change by being imbued with intentionality and integrity, honouring the convergence of new and old, and being mindful of divergence in contexts in existential crisis.

\section{Asanda's narrative: Education for critical consciousness}

I set out at the beginning of my career at CPUT, to be a transformative intellectual. I was a middle class, black (African), female teaching Political and Business Reporting and Editorial Management to mostly working class, female, black (Coloured and African) students. This had implications for my approach to teaching. Although South African universities are now more racially integrated than before, students' engagement with each other was still affected by racial, cultural, linguistic, and socio-economic divisions.

My teaching philosophy was also influenced by Freire's philosophy of education. Education for Critical Consciousness is the main thesis of Freire's revolutionary method of education (Saleh, 2013). It takes the life situation of the learner as its starting point and the raising of consciousness and the overcoming of obstacles as its goals. Freire (Saleh, 2013) used the term 'banking education' to criticize traditional methods which transmitted knowledge from teacher to student through a predetermined curriculum. Like Friere, I wanted the education system to offer students the opportunity to develop their ideas and realize their abilities as active subjects in changing the world around them, an important skill for journalists especially (Saleh, 2013).

Positionality was a key concept in my course development. The cornerstone of journalism is that journalists are objective, neutral observers of 'facts and happenings'. Like most critics of the notion, I believe that objectivity is an unrealistic, unattainable and undesirable goal for journalists, particularly in countries with a history of prejudice like South Africa. I believe that we are all subjective and wanted to teach student journalists how to be conscious of their subjectivity while reporting. I had to build a curriculum that would address this but before I could develop a curriculum - I had to ask some questions about who I was, who the students were and what knowledge we all brought to the classroom. Asking these questions led me to seek knowledge about pedagogy and how it impacts learning. I then began to explore various pedagogies and education theories.

I decided to use the critical theory lens with race, class, and gender as theories as the framework for curriculum development. This challenged my students to think about their positionality in their approach to stories which illustrated the impossibility of objectivity. As I began to challenge them, they began to challenge me about my own class positionality and relationship based on hierarchy with students. As a black female I could relate to racial and gender discrimination but there was a class difference between me and the students which I had to deal with. I had to think very hard about the impact of my own middle-class upbringing and schooling on my ability to teach working class students to be critical of issues of class.

It became clear that before helping students to examine class issues, I had to examine myself and my own expectations of higher education which were based on having attended 
privileged universities in South Africa and abroad. It took time to acclimatize and differentiate between teaching and research at a traditional university like the ones I had attended versus teaching and learning at a university of technology. It is only after I had a better understanding of the history and nuances of a university of technology that I began to see a clearer picture. I was then able to think through and engage with class and its implications in teaching and learning methodologies. I had to quickly figure out new ways of teaching students how to use technology and the tools available through technology without disadvantaging those who had no prior access to technology in high school. I also had to think of methods to teach politics and business reporting which were complex subjects in a way that was accessible to students who had not studied history or business economics in high school.

In the beginning students wanted to be taught with PowerPoint only so they could copy and paste notes and study and pass exams and tests. This was different to the approaches to teaching and learning that I wanted to pursue. Over time, I managed to slowly shift students away from PowerPoint focused learning to being able to have more discussion focused classes based on engagement with readings before class which enriched our discussions more. Teaching in the beginning was a difficult process with lots of resistance from students but with time they came to accept my methodologies and even suggested different ways of approaching lessons and assessments once they were used to the new methods of teaching. By the end of the first year, we were co-creating curriculum using tools like digital storytelling and its assessment together and students' approach to knowledge and meaning making was remarkably different. Students went from passive recipients of knowledge to active agents in their own education.

\section{Kharnita's narrative: Making epistemic plurality possible}

Arriving at the University of Cape Town anthropology department in 2016, after the first shocks of the \#RMF and \#FMF Movements, devising new curricula and rethinking pedagogy was urgent and possible. Whilst course redesign is not uncommon within anthropology and our department, student-led demands for decolonial pedagogies allowed epistemic and pedagogical shifts to happen. I brought a black feminist sensibility to my pedagogy that recognised and grappled with our canons' androcentric and racist imaginaries. Recalling the horror of reading canonical anthropological texts but also the profound epistemic shifts borne by liberatory anthropological texts, I redesigned our third-year anthropology research course, Anthropology Through Ethnography, to explicitly engage a process of discovery that was decolonial in orientation. The course typically has between fifty and sixty students.

The decolonial principles I arrived at were:

- Teaching undergraduate students the elements of theory building in an accessible way

- The cultivation of an intellectual sensibility and curiosity which did not engage with anthropological canon and theory in a chronological fashion but rather in response to students' political concerns 
- Enquiry-based learning and ownership of knowledge in which students directed their learning of anthropological theory and methods based on their concerns

- Plural epistemologies and building epistemic communities which encouraged multiple approaches to research questions and done so in relation to others who have similar interests and concerns

Students were to develop a relationship to disciplinary history that recognises the welldocumented violence of anthropology's past and also remember that anthropology is diverse with thinkers who shifted epistemic boundaries towards a liberatory politics for their time. Course assessments facilitated enquiry-based and peer-to-peer learning. Students determined their epistemic grounds through writing a manifesto for a liberatory anthropology which was published to the class as a blog. Students chose group members based on epistemic affinity towards building epistemic communities. Groups then developed course outlines with annotated bibliographies based on their collective interests. Throughout the course, they conducted a series of practical research tasks. The course outlines formed the basis of their bibliography for a group ethnographic essay. Course readings and lectures - aimed at cultivating praxis - covered elements of theory building pertaining to anthropology: (history of anthropology and) ontological presuppositions, liberatory epistemologies, methodology, ethics, politics, and representation. Some of the questions the course content engaged were:

- Which world are you imagining and who (and what) is included and excluded?

- How do you relate to the world?

- Which procedures can be used to learn about the world?

- How are relationships governed and power constituted in the world you imagine?

- What does it mean to be an ethical subject?

- How does one represent the world as part of an ethical and political project?

Students were also introduced to anthropologists who work(ed) against the mainstream such as decolonial, postcolonial and feminist anthropologists. The very detailed course outline was used as a pedagogical tool and not only a schedule of activities. The rationale for each activity and assessment was outlined with short essays about the production of knowledge and knowledge formation. My course outline provided links to examples that students could use to craft their manifestos, course outlines and projects. Related to the possibility of canon formation, I wanted to challenge students' expectations of being recipients of knowledge. I wanted students to take responsibility for their own learning and move them from largely knowledge consumption to being aware of themselves as knowledge producers.

Facilitating enquiry-based learning proliferated plural epistemologies as students and their interests are diverse. Giving students the tools to imagine the worlds they want, enabled epistemic multiplicity to emerge. Students' liberatory imaginings in their manifestos provided the grounds for their groups to come together, to work on sourcing and engaging reading material 
in common and thus develop a collective and collaborative research project. Peer to peer learning within groups allowed students to recognise that knowledge formation occurs in epistemic communities among whom knowledge is justified, negotiated and deployed. Students were able to learn experientially that knowledge-making is not static nor without boundaries. Whilst the course allowed for the emergence of plural epistemologies, there were limits. What texts students read, what they experienced based on their methodological engagement, who their group members were and levels of commitment to the group are all the factors that go into making epistemes. I wanted students to experience knowledge-making as a self-aware praxis, so they recognised knowledge as something that is worked at and 'we' are able to subvert, resist, negate, and play with ideas. More importantly, texts and forms of knowledge are produced by people in communities who justify particular ideas. Giving students the tools to claim the right to produce knowledge because knowledge is not static, monolithic or eternal, based on their concerns for the world, is where a decolonial curriculum resides.

\section{Bradley's narrative: In the wake of catharsis}

Taking on a teaching post as a new academic may involve being handed an established module or entire curriculum for delivery. Assuming a new teaching post in 2015, I was assigned a module within the Tourism major in my department whose title and managerially-focused content abraded my identity and academic commitment as a human geographer. I found myself at both a personal and a curricular border, which following Amin (2016: 262), is one that is '... interpreted as restricted and circumscribed with prescribed objectives, content, practices, activities and assessments for narrow regulatory purposes'.

My transition forced me to confront the border between my own identity, my discipline and the context of my teaching. I was forced to confront my identity and positionality as white, middle-class, able-bodied, gay male lecturer in an historically black institution of higher learning. As a scholar and teacher, I understand the border between me and my students to be inscribed by race and culture, and the narrowly circumscribed border of an established curriculum. 'Newness' for me was about curricular relevance when faced with inherited teaching material, and about having my teaching speak to a moment in the academy, my institution, and within South Africa more generally. Neither myself nor my discipline were evident on the pages of the established module outline that I was meant to deliver. It was for me a deeply reflective and cathartic moment. Catharsis refers alternately to the purging or purification, especially of emotions; or the surfacing of repressed ideas or experiences that relieves tension (Collins English Dictionary, 2014). Cathartic events are those that destabilise the status quo and make way for something new to emerge and to be transformed.

In their discussion of transformative learning, Alterio and McDrury (2003) highlight the power of reflection and storytelling. They argue that some forms of catharsis can remove obstructive feelings in the learning process and may thus release spontaneous and productive insights. While they write about the experience of reflection in order to help students inform, develop and enhance their learning, a reflexive stance can also assist new academics in 
assessing, reframing and contextualising their teaching. The reflexive journey may not be wholly positive or comforting, however. It may also involve cathartic moments that rupture the relative stability of the present. Diverging from the curriculum that I inherited allowed a release of new insights that helped me to embrace the current context of learning and the knowledge that my students and I bring to the classroom. My cathartic experience helped me to find and realise my agency within the context of my discipline and the learning environment of my institution. I sought to engage 'authentic learning' (Bozalek, et al., 2013; Herrington and Oliver, 2000) in my teaching practice. The adoption of authentic learning principles helps to promote real-life applications of knowledge, while leading to '...an intense feeling of engagement with the learning...' (Bozalek, et al., 2013: 2). Authentic learning provided an epistemic catharsis where students value everyday experiences that link theory and practice to their lived worlds. At the same time cathartic events helped to disrupt my teaching practice, my reflections also require me to face the historical weight that my discipline of geography bears in the colonial project through locating, mapping and colonising territory. At a time when de-colonisation was critical, the negative association with my discipline needed to be addressed.

This cathartic border crossing experience illustrates the challenges that new academics face as they merge into established teaching practices and module content. New academics have the opportunity to bring fresh approaches to established, and often static, teaching and learning practices. In my case, a cathartic encounter with established content enables me to successfully reframe the module using geographical theory, to revise learning outcomes, activities and assessment, and to re-imagine tutorials. My experience demonstrates the opportunities in reflecting on established curricula and finding ways to align teaching and learning with the institutional context in which I work, the intended attributes of our graduates, and with current disciplinary debates. The end result of my efforts is to push the borders of the curriculum, to cross along with my students to new territory, and to undo cognitive damage (Amin, 2016) brought on by ill-suited curricula and teaching practices. My work seeks to enable students to enact their own agency as thinkers and urban citizens.

\section{Analysis and Discussion}

Our individual narratives are focused on curricular change and transformation which were influenced by our positionalities and the political moment. Below we examine these confluences through reflexive pedagogies and border crossings. This lends further credence to the notion that our 'selves' matter in the work that we do.

\section{Reflexive and emergent pedagogies}

We all utilised reflexivity in formulating curricular revisions. Although we were all influenced by standpoint theories based on gender, race, and sexuality where positionality is important in producing knowledge and the connection between knowledge and politics is central (Harding, 1992), how positionality and reflexivity were utilised as pedagogical principles differed. Utilising 
reflexivity as foundational in the construction of knowledge necessitated crafting reflexive pedagogies. For Asanda, the recognition that knowledge is deeply imbricated with a journalist's identity requires teaching students strong objectivity ${ }^{5}$ (Harding, 1992, 1995). Kharnita asked students to consider who they were but also to imagine what intellectual project their future self might desire to work on and how they were transformed by their epistemic communities. Both Bradley and Asanda were deeply influenced by generating knowledge from everyday experience which called on educator and student to recognise the relation between theory and their navigation of the world. Kasturi invited new academics to consider their projects and commitments in higher education and decide how far they were prepared to go to change colonial ways of teaching and relating to students and to each other.

Reflexive pedagogies are not without challenges. Iszatt-White, et al. (2017) caution that being unwilling to cede authority premised on the command of theory, reflexive pedagogies might reinforce and highlight power relations and dependencies between teachers and students. The ways in which the authors used reflexive pedagogies enabled epistemological access (Mgqwashu, 2011) and made the curriculum less rigid and overdetermined by our disciplinary traditions by allowing students to negotiate their disciplines from their positionalities. Reflexivity as shown by Pillow (2003), makes room for emergence. Emergent pedagogies, as delineated by Dalke, et al. (2007) recognises students' and lecturers' diversity, and is cognisant that relationships between students are as important as between student and lecturer and aware that the world outside of the classroom matters. As educators, we sought to bring our pedagogies into conversation with our epistemologies as researchers and practitioners of our disciplinary identities. Disciplinary idioms, combined with our idiosyncratic positionalities as lecturers (Garnett and Vanderlinden, 2011) allowed our students into the classroom in ways we could not anticipate nor control. Teaching students that who they are has a bearing on the ways in which their professional practices emerge is crucial in contending with universalist notions that reproduce epistemic coloniality (Mignolo, 2007) embedded in Northern hegemony. Teaching the politics of knowledge production in disciplines and spaces, such as the journalism department at CPUT, where positivist presuppositions have been inherited and continues despite being contested and debunked elsewhere in the academy creates transformative possibilities for professional praxis.

Reflexivity that asks students who they are in the present and what future they will work towards in conjunction with thinking about ethics and politics, is premised on a continuous reflexive process. Neither students nor other producers of knowledge are imagined as stable, always knowable and predetermined by their identities. Rather, the formation of knowledge and its producers are in a state of becoming that is not a product of an individual intellect which can then be directed towards a liberatory praxis. Making students aware that reflexivity matters throughout the research process, from how one reads to whose voice has the most influence in

\footnotetext{
${ }^{5}$ Strong objectivity, as theorised by Harding $(1992,1995)$, rather than producing subjective knowledge, makes the grounds through which knowledge emerges transparent. Contending with the effects of positionality also makes power relations, the legitimacy and authority of particular knowledge bearers perceptible.
} 
a group discussion, also models historical consciousness. Practising reflexivity as an educator satisfied our desires for more inclusive pedagogies that reckoned with the particularities of our time and space. Being aware that we were teaching from somewhere to people who were not blank slates destabilised the origins of knowledge and how it is understood by students. Teaching is not a value-neutral endeavour as teachers are all located in diverse histories. Pedagogies that presume all pedagogical viewpoints and concerns are the same, produce a violence which reduces the possibility for theory to meet life and explain its complexity. Cultivating reflexive praxes for ourselves by seeking to change all three domains of curriculum change - knowledge (discipline-specific competencies), action (practice of disciplinary competencies), and self (educational identities) (Barnett, et al., 2001) - produced student-centred pedagogies. Reflexive pedagogies, as shown in our narratives, have multiple and diverse entry points. Whilst practising reflexivity is certainly not new in all places, or for all disciplines, the narratives show that pedagogy is connected to our epistemic sensibilities. This synergy between teacher positionality and pedagogy makes it possible to negotiate new, exciting, sometimes uncertain borders between students and teachers, different forms of knowledge and the generational differences within our disciplines. Whilst evident that our pedagogies evinced a desire for new epistemologies and disciplinary praxes to be made possible, what we were doing was redefining, for ourselves and our students, what our disciplines entailed.

\section{Bordering disciplines}

The successes and failures we achieve in border crossing help us to realise our and our students' agency. While borders might be tangible and obvious in some instances, invisible borders are often more difficult to cross. In curriculum terms, these borders are both enunciated from geographies and biographies (Mignolo, 2007) that favour a northern episteme and ways of being that masquerade as well intentioned and appropriate for all. From a decolonial perspective, these borders are pervasive as they double up as metaphors of coloniality that serve to entrench and limit possibilities for change. Borders are also invasive in that they permeate the intersectional ways in which we relate to each other and our students. Crossing borders across gender, sexuality, feminism, patriarchy, class, race, ableism, and so on, requires emotional and academic labour that surpasses the traditional view of what it means to be an 'academic' or lecturer in the academy. Yet, we have to embrace these challenges to realise the goals and commitments we bear towards a socially just higher education.

Another aspect of our border crossing efforts is redefining disciplinary boundaries. In the Tourism narrative, crossing borders is demonstrated by an appreciation and active engagement of interdisciplinarity. Moving beyond the confines of our curricula and disciplines, we have found ways to embrace epistemic diversity and disobedience, plurality, the acknowledgment of boundaries, and the obligation to cross disciplinary borders. Bradley has done so by applying geographical thought to tourism studies; Kharnita has embraced the manifesto from her students that sought to break out of the canon prescribed by anthropology; and Asanda engages with critical theories of race, gender and class within an institutional context where doing so was not 
normalised to unpack South African society and the role that the media play within it. However, whilst we sought to redefine what journalism, anthropology, geography or lecturer training might be, we were not creating new disciplines as much as making the forms of knowledge within our disciplines more inclusive. Our insights from critical race, decolonial, and postcolonial theory, feminist and queer theory and our disciplinary knowledges were mobilised in our pedagogies towards our desires for intradisciplinary change and disciplinary renewal (Krishnan, 2009; Shumway and Messer-Davidow, 1991). The borders within and who counts as a legitimate producer of knowledge are what we with our students, are seeking to transgress. Exclusion from disciplines was not limited to class and gender; race, sexuality, able-bodiedness and other modes of exclusion were also normalised. Our positionalities reflect shifts in disciplinary memberships within contemporary universities and thus dismantle the political boundaries which ground the epistemologies we have inherited. The reflexive pedagogies we and our students engage with is a refutation of disciplinary decadence (Gordon, 2014) and an assertion of the multiplicity of being.

Border-crossing is an unfinished process with horizons of possibility that are not infinite. We are mindful of the neoliberal university's expectation of constant innovation and renewal. Border-crossing as an epistemic tactic with perpetual borrowing, experimenting and cobbling together new epistemic trajectories can be a means of following academic fashion (Gruba, et al., 2004). Reflexive and emergent pedagogies require sensibilities attuned to social justice and a vision of an equitable society in which we and our students have a stake. Maintaining disciplinarity despite renewal also forces us to reproduce and sustain our disciplinary silos. Whilst reflexivity is necessary as a means to engage with knowledge, it is not without the problem of reifying identity or presuming that we are transparent and knowable to ourselves and others. Giving our students the tools to remake the disciplines we have inherited is not the same as giving them the tools to dismantle the structure of the university. In our teaching practice we make our ultimate concerns known to others, then move into the 'project' phase. In this case our shared project revolves around the related goals to emancipate South African higher education from discrimination; to get to know our students; and to advance social justice through our pedagogical practice. It is in this final 'practice' phase, where we become known for the work we do as 'social actors'.

\section{Conclusions}

The disciplinary shifts we instituted, for ourselves and our students, through reflexive pedagogies that facilitated border crossings to bring new disciplinary possibilities into view, demonstrate why it is important to have people writing and teaching from multiple perspectives. It is particularly important to have people from groups that have been socio-politically subjugated and denigrated by coloniality teaching and challenging disciplines. Changing our disciplines and our universities requires educators whose situated knowledge (Haraway, 1998) enable situated pedagogies to come to fruition. Situated pedagogies disrupt the binaries between students and lecturers and between knowledge and being. Positionality, when brought into the classroom towards liberatory and transformative ends, allows us to address our and our students' ultimate concerns. Border crossings that are decolonial, as not all border crossings are necessarily 
liberatory, require us to relinquish mimicry of the global North. Modes of reflexive pedagogy, however they are constituted ask us and our students to centralise our concerns through epistemologies that do not alienate us and therefore begin to ask and respond to the questions that animate our time and space.

The ubiquity of calls to decolonise education in the present, may well be read as fashion within certain quarters. As individuals, however we are driven by our lived experience to produce curriculum change. Todd and Robert (2018: 70) state that '... decolonial frameworks work towards healing, resurgence and renewal in the wake of ongoing colonial trauma'. They further note that producing decolonial curricula are ongoing processes with many challenges. Our commitment to decolonial praxis, whilst benefiting from the insurgency of decolonial thinking in the present goes beyond academic fashion. Our approaches, rather emerged from the desire to craft pedagogies we wished we had been on the receiving end of as students and young scholars. We rewrote our curricula not as theorists of education with a long-studied history of pedagogical shifts that also draw upon a canon. The borders we crossed in each of our pedagogies differed and in many ways were fairly heterodox and emergent praxes. It is within this plurality of responses that a decolonial promise is held.

Curriculum change is not new; what is new is this political moment. The massification of higher education in postapartheid South Africa and attempts at producing post-racial institutions has also entailed entry into the university of new constituencies. This has enforced a politics of recognition where epistemic violence has not gone unnoticed or unremarked. Our curricula responses have been our attempts to bring our and our students' lived experiences into the classroom so as to heal the violence of an exclusionary education system. We should not however assume that all curriculum change and all border crossings are decolonial or liberatory. Or that curricular change can be sedimented to produce resilient and enduring politics of inclusion. The resurgence of the far right globally who advance racist, homophobic and patriarchal modes of politics are also responding to this political moment with new curricula and wielding the institutional power to silence and sanction inclusionary epistemes. Further, precarity in the contemporary university, as half of our stories show, means that the impact of curricula change is sometimes a temporary measure. That same precarity impedes possibilities for future research with student responses that would be vital. Given the precarious nature of academic labour, long term engagements with students and curriculum change is dependent on who is still employed and who can commit to the process. The possibility for changing what and how we teach exists, but without security of tenure to those who have ordinarily been excluded, the stultification of the curriculum will continue. What is more the possibility of transmitting new imaginaries for socially just and equitable societies will be fleeting.

Returning to Freire's epigraph, we acknowledge and embrace our positionalities in our teaching roles and our reflexive stance recognises we are neither impartial nor objective. As new academics who have crossed - and continue to cross - myriad borders, we are not fixed observers of facts and happenings. Rather our teaching practices seek to contribute to the re-imagining and future directions in higher education curricula in South Africa. 


\section{Author Biographies}

Bradley Rink is Senior Lecturer in the Department of Geography, Environmental Studies \& Tourism at the University of the Western Cape (UWC) focusing his research and teaching on mobilities, urban place-making and tourism. He is the recipient of the 2017 CHE-HELTASA National Excellence in Teaching and Learning Award.

Kharnita Mohamed is a Social Anthropology Lecturer at the University of Cape Town. She is working on a PhD in Women's and Gender Studies at the University of the Western Cape focused on disability from a decolonial feminist perspective. Her debut novel, Called to Song (Kwela), was published in 2018.

Asanda Ngoasheng is a former political reporting lecturer at CPUT. She is currently a Research Associate at the Sussex Rights and Justice Centre. Her areas of research are decolonisation, race, class and gender in media, politics and education. She assists academics in different institutions to develop contextually relevant curricula for social and spatial justice.

Kasturi Behari-Leak is a senior lecturer in academic staff and professional development at the University of Cape Town; President of HELTASA and President-elect of ICED; was co- chair of the Curriculum Change Working Group and serves on the advisory sub-committee for the World Universities Network. She has published in leading journals in higher education studies.

\section{References}

Alterio, M. \& McDrury, J. 2003. Learning Through Storytelling in Higher Education: Using Reflection and Experience to Improve Learning. London: Routledge.

Amin, N. 2016. Curriculum WITHOUT BORDERS? In Samuel, M., Dhunpath, R. \& Amin, N. (eds.) Disrupting Higher Education Curriculum. Rotterdam: Sense Publishers, 291-303.

Archer, M.S. 2000. Being Human: The Problem of Agency. Cambridge: Cambridge University Press.

Archer, M.S. 2003. Structure, Agency, and the Internal Conversation. Cambridge: Cambridge University Press.

Barnett, R. Parry, G. \& Coate, K. 2001. Conceptualising Curriculum Change. Teaching in Higher Education, 6(4): 435-449.

Behari-Leak, K. 2017. New academics, new higher education contexts: A critical perspective on professional development. Teaching in Higher Education, 22(5): 485-500.

Biggs, J. \& Tang, C. 2011. Teaching for Quality Learning at University, 4th Edition. New York: Society for Research into Higher Education and Open University Press.

Bozalek, V., Gachago, D., Alexander, L., Watters, K., Wood, D., Ivala, E. \& Herrington, J. 2013. "The use of emerging technologies for authentic learning: A South African study in Higher Education." British Journal of Educational Technology, 44(4): 629-638. 
Carbado, D. W., Crenshaw, K. W., Mays, V. M. \& Tomlinson, B. 2013. Intersectionality. Du Bois Review: Social Science Research on Race, 10 (2): 303-312.

Chikane, R. 2018. Breaking a Rainbow, Building a Nation: The Politics Behind \#MustFall Movements. Johannesburg: Picador Africa.

Collins English Dictionary, 12th ed. 2014. "Catharsis." Available at: http://search.credoreference.com.ezproxy.uwc.ac.za/content/entry/hcengdict/catharsis/0 (accessed 15 April 2018).

Council on Higher Education. 2017. Decolonising the Curriculum: Stimulating Debate. Briefly Speaking no. 3: 1-12.

Curriculum Change Working Group (CCWG). 2018. "Curriculum Change Framework UCT." Available at: http://www.uct.ac.za/sites/default/files/image_tool/images/328/ teaching/ccwg/UCT-Curriculum-Change-Framework.pdf (accessed 11 December 2018).

Dalke, A. F., Cassidy, K., Grobstein, P. \& Blank, D. 2007. Emergent pedagogy: Learning to enjoy the uncontrollable - and make it productive. Journal of Educational Change, 8(2): 111-130.

Elder, G. 1999. 'Queerying' Boundaries in the Geography Classroom. Journal of Geography in Higher Education, 23(1): 86-93.

Farber, T. 2015. "UCT in Turmoil." Times Live, 17 March. Available at: https://www.timeslive.co.za/news/south-africa/2015-03-17-uct-in-turmoil/ (accessed 11 December 2018).

Freire, P. 1985. The Politics of Education. Basingstoke: Macmillan.

Freire, P. 2000. Pedagogy of Freedom: Ethics, Democracy, and Civic Courage. Oxford: Rowman and Littlefield Publishers.

Garnett, R. F. \& Vanderlinden, L. K. 2011. Reflexive pedagogy: Disciplinary idioms as resources for teaching. Teaching in Higher Education, 16(6): 629-640.

Giroux, H. 1992. Border Crossings: Cultural Workers and the Politics of Education. New York: Routledge.

Gordon, L. 2014. Disciplinary decadence and the decolonisation of knowledge. Africa Development, 39(1): 81-92.

Gruba, P., Moffat, A., Søndergaard, H. \& Zobel, J. 2004. What drives curriculum change?" Proceedings of the Sixth Australasian Conference on Computing Education, 30: 109-117.

Hall, M. 2015. Institutional culture of mergers and alliances in South Africa. In Curaj, A., Georghiou, L., Harper, J. C., \& Egron-Polak, E. (eds.) Mergers and Alliances in Higher Education. London: Springer Open.

Harding, S. 1992. Rethinking standpoint epistemology: What is 'strong objectivity.' The Centennial Review, 36(3): 437-470.

Harding, S. 1995. 'Strong Objectivity': A Response to the New Objectivity Question. Synthese, 104(3): 331-349.

Herrington, J. \& Oliver, R. 2000. An instructional design framework for authentic learning environments. Educational Technology Research and Development, 48(3): 23-48.

hooks, b. 1994. Teaching to Transgress. London: Routledge. 
Iszatt-White, M., Kempster, S. \& Carroll, B. 2017. An educator's perspective on reflexive pedagogy: Identity undoing and issues of power. Management Learning. 48(5): 582-596.

Jackson, S. 1997. Crossing borders and changing pedagogies: From Giroux and Freire to Feminist Theories of Education. Gender and Education, 9(4): 457-468.

Krishnan, A. 2009. What are academic disciplines? Some observations on the disciplinarity vs. interdisciplinarity debate. University of Southampton, National Centre for Research Methods Working Paper Series 03/09.

Mignolo, W. D. 2007. Delinking. Cultural Studies, 21(2): 449-514.

Mgqwashu, E. M., 2011. Reflexive pedagogy for reading across the curriculum: The University of KwaZulu-Natal Faculty of Education experience. Perspectives in Education, 29(4): 22-37.

Ndelu, S. 2017. A rebellion of the Poor: Fallism at the Cape Peninsula University of Technology. In Langa, M. (ed.)\#Hashtag: An Analysis of the \#FeesMustFall Movement at South African Universities. Johannesburg: Centre for the Study of Violence and Reconciliation, 6-12.

Pillow, W. 2003. Confession, catharsis, or cure? Rethinking the uses of reflexivity as methodological power in qualitative research. International Journal of Qualitative Studies in Education, 16(2): 175-196.

Quinn, L. (ed.) 2019. Re-imagining Curriculum: Spaces for Disruption. Stellenbosch: African Sun Media.

Richardson, L. 2000. "Writing: A method of inquiry." In Denzin, N. K. \& Lincoln, Y. S. (eds.) Handbook of Qualitative Research, 2nd Ed. Thousand Oaks, CA: Sage, 923-948.

Saleh, S. E. 2013. Paulo Freire's philosophy on contemporary education. ELT Journal, 15(1): 91111.

Shumway, D. R. \& Messer-Davidow, E. 1991. Disciplinarity: An introduction. Poetics Today, 12(2): 201-225.

Todd, K. L. \& Robert, V. 2018. Reviving the spirit by making the case for decolonial curricula. In Wane, N. N. \& Todd, K. L. (eds.) Decolonial Pedagogy: Examining the Sites of Resistance, Resurgence and Renewal. Basingstoke: Palgrave Pivot, 57-72.

University of the Western Cape, 2020. "UWC History". Available at: https://www.uwc.ac.za/Pages/History.aspx (accessed 20 March 2020). 